\title{
MINIMARKETS EXISTENCE ON SALES TURNOVER OF THE TRADITIONAL SHOPS
}

\author{
Neni Murniati \\ nenimurniati.feunpas@gmail.com \\ Universitas Pasundan \\ J1. Tamansari No. 6-8, Bandung 40116
}

received: 19/6/19; revised: 24/9/20; approved: 14/12/20

\begin{abstract}
This paper summarizes the results of a study that explains the impact of minimarkets existence on the sales turnover of traditional shops in Ciledug Subdistrict, Cirebon Regency in 2017, West Java, Indonesia. Through a statistical method - called the difference test - the existence of minimarkets in Ciledug Subdistrict has significantly reduced the sales turnover and reduced the number of buyers of the traditional shops, on the other hand the number of working hours of traditional shops has increased. This study also uses the regression model to explain the effect of the number of buyers, traditional shops' working hours, and the distance between traditional shops to the nearest minimarkets on the sales turnover of traditional shops. This study shows that all independent variables simultaneously significant affected on the sales turnover of traditional shops. Partially, the number of buyers and the distances between traditional shops to the nearest minimarkets significantly influence the sales turnover of traditional shops, but the working hours of the traditional shops does not has a significant effect.
\end{abstract}

Keywords: minimarkets; traditional shops; sales turnover; different test; regression model

\section{INTRODUCTION}

The era of globalization is in progress, requiring all economic resources in the world to move mobile in all directions. Every economic actor should follow the flow of globalization which is impossible for anyone to stop. The market mechanism system is being targeted by every economic actor so that a higher level of economic activity can be achieved quickly and with the right target.

Every economic resource that interacts in the era of globalization must have the appropriate criteria for interacting in the era of globalization. The era of globalization is closely related to the perfect competition market structure, where all resources must be able to move in all directions. Human resources as the main economic actors are the most important economic resource, they must have capability to manage other economic resource for the best goals, so that they must mastery in technology and science in order to win in the global competition.

Advances in technology and science have given rise to various kinds of innovations. The theory of economic development according to Joseph Schumpeter states that innovative entrepreneurs will encourage economic growth in a region. Schumpeter said, there are the typical characteristics of innovative entrepreneurs are: intelligence, alertness, energy and determination. Schumpeter also said, that entrepreneurship is innovation and the actualization of innovation. He divided the innovation process into four dimensions: invention, innovation, diffusion and imitation. Schumpeter in his early work presents the following entrepreneurship definition: The function of entrepreneurs is to reform or revolutionize the pattern of production by exploiting an invention or, more generally, an untried technological possibility for producing a new commodity or producing an old one in a new way, by opening up a new source of supply of materials or a new outlet for products, by reorganizing an industry and so on (Sledzik, 2013). This opinion is in line with what was said by contemporary economist, Frederic S Mishkin, who stated that the development process is a process of increasing aggregate production due to an increase in the productivity of each economic resource used through technological advances and innovation (Mishkin, 2015). This increase in the productivity of economic resources is the result of technological advances and innovation that the classical economist Robert Malthus did not predict. Malthus's prediction does not include technological developments in production activities, he believes that in the future there will be excess demand for foodstuffs. This is 
related to Malthus's opinion that population growth follows exponential growth, while growth in the amount of food is arithmetic growth. Now, Malthus' belief is not proven, because technological developments have increased aggregate production which can offset the demand side. In addition, Malthus's opinion has become the subject of criticism from economists, namely in terms of population growth, food production, global trade, and calculation (Agarwal, 2020).

All innovations aim to increase the productivity of each input which will increase the aggregate output, resulting in a certain amount of input producing a larger amount of output. Of course, increasing the productivity of each input will encourage production activities to be more efficient and effective. The decrease in production costs - due to the increase in the productivity of each input - will ultimately increase the company's profits. On the other hand, an innovative entrepreneur will think based on science in reinvesting company profits that have been earned, which in the end this reinvestment process causes the aggregate output level to rise to a greater level for the benefit of a larger company as well. This increase in aggregate output is what we know as 'economic growth'. Thus, economic growth is the rise in output in the economy (Colander, 2020).

Advances in technology and science will lead to an increase in the productivity of each input, business efficiency and company profits. Over time, the company will be able to increase the scale of the factory or the size of the factory which causes the unit cost of production activities to get lower. This area of business, in Microeconomics is called an "economies of scale" area (Pyndick \& Rubinfeld, 2013). Efforts to increase the company's plant size can be done by increasing the number of business branches in various places. Opening a new branch of a company requires sufficient capital, technology, science, and other resources.

The opening of new company branches aims to increase company profits by increasing sales turnover. The sales turnover is the total revenue of products sold by the company. In microeconomics, sales turnover is also known as the company's total revenue. Mathematically, the sales turnover is the multiplication of the unit price of the good and the quantity sold (Colander, 2020). Increasing the company's sales turnover can be done by increasing the unit price of the product and (or) increasing the quantity sold. In a perfectly competitive market - that characterizes the era of globalization - a producer acts as a "price taker", because the price per unit sold by the producer (company) is tended to be determined by the market (Pyndick \& Rubinfeld, 2013). Criteria for the products sold by these producers tend to be homogeneous, therefore the sales strategy carried out by producers to increase the sales turnover is trying to increase the quantity of goods sold. Efforts to increase the quantity of goods sold can be done by attracting as many buyers as possible, therefore it is necessary to think about service methods that are more attractive to consumers. Minimarket is one solution in answering this challenge.

Minimarkets are the product of technological developments and innovations that collaborate human resources, technological advances, other resources, and sizeable capital resources. Minimarket define as a store that sells food and other goods, but is not as big as a supermarket. Without sufficient of capital resources, it is impossible for the minimarket can operate. Therefore, investors who have sizeable capital are able to build minimarkets, such for the buildings and other capital goods. Minimarkets are the choice of global consumers who want convenience and comfort in shopping. Minimarket can be a solution that must be developed by entrepreneurs in the era of globalization with the aim of obtaining greater profits. The type of innovation developed by the minimarket is a service system to customers that is more concise, easy, and convenience.

Many residents in remote areas - such as in Indonesia - depend on their livelihoods as traditional shop traders. They sell products that are almost the same as the products sold by minimarkets. The business capital for traditional shops is not as much as that of minimarkets. Their profits are not large, just enough to cover their daily living expenses. As traders, they serve the buyers themselves, as well as cashiers. The existence of minimarkets in rural areas may become a competitor for existing traditional shop entrepreneurs. The proliferation of mini-markets in rural areas may be the cause of the decline in sales turnover of traditional shops, especially if the distance between traditional shops and minimarkets is very close. Various shopping conveniences as well as the marketing system implemented by minimarkets, can attract consumers to switch from traditional shops to minimarkets which in turn reduces the sales turnover of traditional shop owners. The existence of minimarkets in rural areas allows traditional shops to work hard by opening their shops longer in the hope that the number of buyers will increase so that their sales turnover will increase.

Ciledug Subdistrict is one of the subdistricts in Cirebon Regency, West Java Province which has an area of $1,334,252$ hectares, of which $63.12 \%$ are rice fields, $83 \%$ of the population has livelihoods as traders and service businesses, including being the traditional shop entrepreneurs. Since 2013, there have been many minimarket businesses in Ciledug Subdistrict. According to data from the Office of Industry and Traders (BPPT) of Cirebon City, Ciledug Subdistrict has the highest number of minimarkets in East Cirebon Regency from 2013 to 2017 , namely 25 minimarkets. On the other hand, there are 510 traditional shops in the same time frame. The growth of the number of minimarkets is feared to have a detrimental effect on the survival of the traditional shops business in Ciledug Subdistrict. 
It is feared that the existence of minimarkets in Ciledug Subdistrict will become a competitor for traditional shops. The existence of minimarkets there will cause a decrease in sales turnover of traditional shops due to the alleged decline in the number of consumers. One of the efforts to maintain the sales turnover of traditional shops is to increase shop opening hours, but will the addition of traditional shops working hours help increase their sales turnover? To what extent is the influence of the number of buyers, working hours and distance to the nearest minimarket that affects the sales turnover of traditional shops in Ciledug Subdistrict?

\section{METHODS}

This study uses primary data by distributing questionnaires to the owners of traditional shops as respondents. According to data from the Office of Industry and Traders (BPPT) of Cirebon City, Ciledug District in East Cirebon Regency, from 2013 to 2017 in Ciledug Subdistrict there were 510 traditional shops. From this data and at an error rate of 10\%, then through the Slovin method the number of samples obtained is 92 respondents.

The statistical method known as the different test is used to find out whether there are differences between the variables that want to know the changes due to the existence of a minimarket in the area in question. Through this method, we can find out whether the existence of a minimarket around the grocery shop in Ciledug Subdistrict caused a decrease in the sales turnover of traditional shops? Is there a decrease in the number of buyers to traditional shops? Is there an increase in the number of working hours of the grocery shop?

This study also uses the multiple linear function equation model as an estimation tool to determine the influence of buyers to traditional shops, working hours of the traditional shops, and the distance of the traditional shops to nearest minimarkets, on the sales turnover of traditional shops. The regression equation is (Gujarati \& Gunasekar, 2017).

The data used is cross section data, meaning data obtained from various respondents in one particular period, namely in 2017. Statistical tools used to the regression equation model are: partial test (t-Test) and simultaneous test (F-Test), coefficient of determination test $\left(\mathrm{R}^{2}\right.$-Test), autocorrelation test, and multicollinearity test.

\section{RESULTS}

Before discussing the results of this study, it is best to know the characteristics of the respondents who were the samples in this study. The number of respondents who were sampled in this study were 92 owners of the traditional shops in Ciledug Subdistrict at 2017, who were divided into the following characteristics: (1) age of traders varies from 21 years to 62 years, but the majority of respondents $(28 \%)$ are in the age range of 42 - 48 years; (2) based on gender, $84 \%$ of the respondents are female, and 14 are male; (3) based on the commodities sold, $79 \%$ of respondents sell products that are similar to products sold by minimarkets, the remaining $21 \%$ sell other products; (4) based on the length of the business, the majority (35\%) of respondents opened their business in the 2-4 year range before 2017.

The results of this study found that the existence of mini markets in Ciledug Subdistrict has decreased the sales turnover of traditional shops. According to the results of the different test at the $95 \%$ confidence level, it states that there is a significant difference in sales turnover obtained by the traditional shops between before and after the existence of minimarkets. The results of the study stated that before existence of minimarket the traditional shops had an average sales turnover per day of IDR 1,507,000, - but after existence of the minimarkets the average sales turnover per day dropped to IDR 953,500. So, after the existence of the minimarkets in Ciledug Subdistrict, the sales turnover of traditional shops decreased by Rp. 553,500 per day. A large amount for a traditional shop.

This study found that the number of buyers to the traditional shops decrease after existence of mini markets in Ciledug Subdistrict. There is a significant difference in the number of traditional shops buyers between before and after existence the minimarkets. Before existence the minimarkets the traditional shops were visited by an average of 35 buyers, but after their minimarkets there were only 26 buyers. Thus, the existence of minimarkets in Ciledug Subdistrict has reduced the number of buyers to traditional shops by an average of 9 people per day. The decrease in the number of buyers to traditional shops has led to a decrease in sales turnover of traditional shops after the existence of a minimarkets in Ciledug Subdistrict.

This study also found that the existence of minimarkets in Ciledug Subdistrict led to an increase in the working hours of traditional shops, which are aimed at attracting a larger number of buyers to traditional shops. The different test showed that there is a significant difference in the number of traditional shops working days between before and after existence the minimarkets. Before the existence of minimarkets the traditional shops worked on average for 14 hours per day but after the existence of minimarkets they worked on average for 14.5 hours per day.

Through the multiple linear regression equation model it is intended to find out the extent to which the number the traditional shops buyers, the traditional shops working hours, and the distance of the traditional shops to the nearest minimarket significantly affected on the sales turnover of the traditional shops in Ciledug Subdistrict in 2017. This means that the sales turnover of 
traditional shops in Ciledug Subdistrict is significantly influenced by the number of buyers to the traditional shops, the number of working hours of the traditional shops, and the distance of traditional shops to the nearest minimarkets.

After the existence of minimarkets in Ciledug Subdistrict, the sales turnover of traditional shops in Ciledug Subdistrict is significantly influenced by the number of buyers to the traditional shops, the number of working hours of the traditional shops, and the distance of traditional shops to the nearest minimarkets. The results of processing data through the least squares

Table 1. Summary of The Least Squares Method

\begin{tabular}{lclcc}
\hline \multicolumn{1}{c}{ Variable } & Coefficient & Std Error & t-Stat & Prob \\
\hline $\mathrm{C}$ & -961573.7 & 232278.9 & -4.139738 & 0.0001 \\
$\mathrm{X}_{1}$ & 55886.01 & 5641.429 & 9.906357 & 0.0000 \\
$\mathrm{X}_{2}$ & 9505.606 & 17190.42 & 0.552960 & 0.5617 \\
$\mathrm{X}_{3}$ & 893.5783 & 194.6897 & 4.589756 & 0.0000 \\
R-squared & 784353 & Mean Dep Var & 988206.5 & \\
Adj. R-sqrd & 0.77702 & SD dep var & 776185.2 & \\
SE of regr & 366535.6 & Akaike Inf Crit & 28.50408 & \\
Sum sq resid & $1.18 \mathrm{E}+13$ & Schwartz crit & 26.61373 & \\
Log likelihood & -1307.183 & Hannan-Quin cr & 28.54834 & \\
F-statistic & 106.6916 & Durbin-Watson & 1.891058 & \\
Prob(F-statistic) & 0.000000 & & & \\
\hline
\end{tabular}

method are summarized in Table 1.

From the table of data processing results as shown above, it is written into the Multiple Linear Functions Equation Model as shown below:

$$
\begin{aligned}
\mathrm{Y}= & \mathrm{f}\left(\mathrm{X}_{1}, \mathrm{X}_{2}, \mathrm{X}_{3}\right)=-961573.7+55886.01 * \mathrm{X}_{1}+ \\
& 9505.606 * \mathrm{X}_{2}+893.5783 * \mathrm{X}_{3} \ldots \ldots \ldots \ldots \ldots \ldots \ldots . .(1)
\end{aligned}
$$

in which:

$\mathrm{Y}=$ Total sales turnover per day (Rupiah)

$\mathrm{X}_{1}=$ Number of buyers per day (people)

$\mathrm{X}_{2}=$ Number of working hours per day.

$\mathrm{X}_{3}=$ distance to the nearest minimarket (meter)

The results of simultaneous tests (F-Test) that at the $95 \%$ confidence level all the independent variables (number of buyers, number of traditional shops working hours, and distance the traditional shops to the nearest minimarket) have a significant effect on the sales turnover of traditional shops in the Ciledug Subdistrict in 2017.

The t-test shows that the number of buyers to the traditional shops $\left(\mathrm{X}_{1}\right)$ and the distance of the traditional shops to the nearest minimarket $\left(\mathrm{X}_{3}\right)$ has a significant influence on the sales turnover of the traditional shops. On the other hand, the number of traditional shops working hours $\left(\mathrm{X}_{2}\right)$ does not significantly effect.
Based on the determination test $\left(\mathrm{R}^{2}\right)$ shows that $78.43 \%$ the sales turnover of traditional shops in Ciledug Subdistrict in 2017 is influenced by all the independent variables contained in the model. The autocorrelation test results state that the regression model is located in an autocorrelation-free area, likewise the results of the heteroscedasticity test state that the regression model is free from the problem of heteroscedasticity.

The existence of business competitors often reduces the sales turnover and sales profits, especially when the arrival of competitors is accompanied by a provision of more sophisticated knowledge and technology that is difficult to imitate and apply, and has a strong bargaining position in business activities.

The existence of a minimarket in Ciledug Regency since 2013 makes traditional shop owners fear the life of their shops. The study resulted that the existence of minimarket in Ciledug Regency reduced sales turnover of the traditional shops, reduce the number of buyers, and increase in work time the traditional shops. The existence of minimarkets in Ciledug Regency makes the traditional shops around the minimarkets must to work hard to maintain their business life, they must compete with minimarkets around their shops. They have to figure out how to make their business survive caused by the existence of minimarkets.

According to the table as the result of regression process above we can be read the traditional shops loses as much as IDR 961,573.7 /day if no number of factors affecting the sales turnover as assumed. No buyers, no distance to the nearest minimarkets, and no working hours, they can get loses as much as IDR 961,573.7/day.

The buyers are a market force to maintain business activities and business life. The buyers can increase their sales turnover and their profit. The business actors must maintain their consumers so that sales turnover is maintained ang get profit. From the table above as the result of the study, we can see that an increase in 1 person the number of buyers to the traditional shops at Ciledug Regency led to an increase in the sales turnover of the traditional shops by IDR 55,886.01/day. This figure is certainly a small number when compared to the sales turnover that minimarkets get.

The amount of sales turnover is also influenced by the number of working hours devoted to business activities. The longer the time devoted to business activities, it is hoped that the business results will increase. Likewise, in traditional shops business activities, the more store opening hours it is expected that the sales turnover will increase. The results of this study state that the increase in the number of traditional shops working hours of 1 hour/day caused an increase in the sales turnover of traditional shops at IDR 9,505.606/ day. But based on statistical testing partially, this shows a non-significant effect at the $95 \%$ confidence level.

The distance between the business unit and the competitors has an effect on the sales turnover of the 
business unit. The farther the business unit is from the competitors' places, the buyers tend to approach the business units, but the closer the business units are from the competitors' places of business, the buyers tend to tend to the competitors' places. The results this research state that increasing the distance of traditional shops to the nearest minimarket as much as 1 meter resulted in an increase in the sales turnover of the traditional shops by IDR 893.5783/day.

\section{DISCUSSIONS}

The current economic development process requires the readiness of reliable economic sources in the global era, which are ready to face any competition, including business competition. One of the requirements to face global competition is the availability of suitable economic resources to compete in the global era, especially human resources who always have a passion for innovation. Adequacy of capital resources is no less important for the benefit of business activities. The theory of economic development by Joseph Schumpeter states that innovative entrepreneurs will boost the economic growth. Schumpeter in his early work presents the following entrepreneurship definition: "The function of entrepreneurs is to reform or revolutionize the pattern of production by exploiting an invention or, more generally, an untried technological possibility for producing a new commodity or producing an old one in a new way, by opening up a new source of supply of materials or a new outlet for products, by reorganizing an industry and so on". Schumpeter used the concept of an entrepreneur in his theory, used the concept of an "innovator" (Sledzik, 2013).

Economic growth defined as the growth in the production capacity of goods and services can be produced by the region or country, therefore in the economic growth means there is a development (increase) in the amount of aggregate production and the productivity of economic resources (Mishkin, 2015). Efforts to increase aggregate production in rural areas should also be comparable to efforts to increase new entrepreneurs in rural areas, because the number of entrepreneurs as the innovative entrepreneurs will boost the economy in a better direction (Sledzik, 2013). Efforts to increase aggregate production and business productivity in rural areas are closely related to efforts to increase business efficiency, use of technology, and science. Improving the quality of human resources as business managers is a top priority for the above goals. Therefore, human resource development activities are very important in an effort to increase aggregate production and business productivity in rural areas. In addition, it is also necessary to monitor the implementation of antitrust laws to reduce the power of giant companies which will kill the economic life of the small people.
The growth of production aggregate in an area is identical to the sales turnover obtained by all producers of goods and services in that region. Most of the sales turnover earned by producers is allocated for the next investment purpose so that the resulting output becomes even greater. The amount of sales turnover obtained by producers illustrates the amount of consumer demand for commodities sold by producers at a certain price level. And furthermore, the more working hours required in business activities, the greater the sales turnover obtained. On the other hand, sales turnover is also influenced by the existence of competitors, especially in selling similar goods. The sales turnover of a business unit will be disrupted if it faces strong competitors. $\mathrm{He}$ must try hard against these competitors to maintain a predetermined sales turnover.

Traditional shops as one of the business activities, they have competitors, minimarkets are competitors to the traditional shops. The arrival of a minimarkets might decrease the sales turnover of traditional shops, lower the number of buyers. Traditional shops are also working to increase their shop opening hours to attract more buyers to their shops so that their sales turnover increases. The close distance between traditional shops and minimarkets allows a reduction in the sales turnover of traditional shops. So that in this study the author assumed that the sales turnover of traditional shop is influenced by the number of buyers, the number of working hours of traditional shops, and the distance from the traditional shops to the nearest competitors. Minimarket entrepreneurs who have come to rural areas have mastered the knowledge of entrepreneurship, therefore they are a serious challenge for business people in rural areas, such as traditional shops. The traditional shops in rural area must strive to increase the level of business competition knowledge so as not to be run over by the arrival of these minimarkets. So that the government's efforts to assist the traditional shops in rural is needed to maintain their life business. The Indonesian government should be proactive in defending small entrepreneurs by implementing regulations that have been established by the government. On the other hand, the flow of globalization, which is difficult to contain, forces everything to run fast and precisely based on the market mechanism system. The market mechanism system that reduces the role of the government in various fields forces the small entrepreneurs to run quickly to catch up with science and information.

\section{CONCLUSIONS}

Business competition in the global era is very sad for remote areas in Indonesia. Indonesia, which is ranked 50th in the Global Competitiveness Index in 2019, must indeed feel the toughness of business competition in the global era. Minimarket as a global product that comes to 
all corners of Indonesia in the era of globalization which is marked by intense competition, cannot be prevented from coming. This is evident from the results of this study, how significant the influence of the existence of mini markets on the sales turnover of traditional shops in Ciledug Subdistrict, Cirebon Regency. This fact is sad. It is a situation that is not comparable between the economic power of newcomers who have the strength of capital and other resources as competitors to traditional shop entrepreneurs. Competitors are in a strong position compared to traditional shops in Ciledug Subdistrict which have limited capital and other resources.

The existence of minimarkets there has significantly reduced the sales turnover of traditional shops and reduced the number of buyers of traditional shops in Ciledug Subdistrict. The lack of strength of the traditional shops in the business competition for minimarkets in Ciledug Subdistrict is shown by the insignificance of the effect of increase in working hour of traditional shops on the increase in sales turnover of traditional shops. If the government does not quickly intervene in maintaining the life of the traditional shops, then slowly the traditional shops will be destroyed. Therefore, more intensive government policy is needed in maintaining a people's economy-based business, especially the economic activities of low-income people in remote areas.

\section{REFERENCES}

Agarwal, P. 2020. Malthusian Theory of Population. www. intelligenteconomist.com/ Malthusiantheory/

Colander, D. 2020. Economics, 11th ed, McGraw-Hills Education, New York.

Gujarati, P. \& Gunasekar, 2017, Basic Econometrics. Mishkin, F. 2015. Macroeconomics Policy and Practice, 2nd edition, Pearson, Global Edition, Columbia University.

Pyndick, R. \& Rubinfeld, D. 2013. Microeconomics, eight edition, Pearson International Edition.

Sledzik, K. 2013. Schumpeter's View on Innovation and Entrepreneurship, Management Trend in Theory and Practice, University of Zilinia, Poland. 